\title{
Mineral contents in the skin and flesh of fruits of apple cultivars
}

\author{
Ricardo Sachini ${ }^{1}$, Cristiano André Steffens ${ }^{2}$, Mariuccia Schlichting de Martin ${ }^{3}$, \\ Bianca Schveitzer ${ }^{4}$, Cristhian Leonardo Fenili ${ }^{5}$, José Luiz Petri ${ }^{6}$
}

\begin{abstract}
Apple is considered a functional food, since it presents considerable contribution in the supply of antioxidants, vitamins and minerals, and its consumption is related to the prevention of various diseases. However, most cultivars released in recent years have been poorly studied regarding their nutritional properties. The aim of this work was to quantify mineral contents in the skin and flesh, of apple cultivars with potential production in southern Brazil. The apple cultivars evaluated were 'Fuji Suprema', 'Castel Gala', 'Lisgala', 'Monalisa', 'Luiza', 'Daiane', 'Venice', 'Elenise' and M.10-09 advanced selection, in the 2017/2018 and 2018/2019 seasons. Among evaluated minerals, considering consumption of a fruit of 115 $\mathrm{g}$ with skin (except carpel and seeds), potassium supplies high percentage of recommended daily intake, followed by phosphorus and magnesium. The calcium content in apples presents low contribution to the recommended daily intake. Due to the higher concentrations of minerals in skin in comparison to flesh, the consumption of whole fruit increases the percentage of minerals ingested. In addition, the evaluated minerals showed significant differences as a function of cultivar. 'Monalisa' cultivar, in the flesh portion, stood out due to the high phosphorus and calcium content, 204.1 and $36.5 \mathrm{mg} \mathrm{kg}^{-1}$ (2017/2018) and 305.6 and $43.8 \mathrm{mg} \mathrm{kg}^{-1}$ (2018/2019), respectively. 'Fuji Suprema', in both harvest seasons, stood out due to the high potassium contents in skin $\left(1073.8 \mathrm{mg} \mathrm{kg}^{-1}\right)$ and flesh $\left(1223.7 \mathrm{mg} \mathrm{kg}^{-1}\right)$ in 2017/2018 and in flesh $\left(1547.3 \mathrm{mg} \mathrm{kg}^{-1}\right)$ in 2018/2019 and magnesium in flesh $\left(122.4 \mathrm{mg} \mathrm{kg}^{-1}\right)$ in 2017/2018 and in skin $(231.2$ $\left.\mathrm{mg} \mathrm{kg}{ }^{-1}\right)$ and flesh $\left(62.4 \mathrm{mg} \mathrm{kg}^{-1}\right)$ in $2018 / 2019$.
\end{abstract}

Index terms: Malus domestica. Nutritional status. Food nutrition.

\section{Teores minerais na casca e na polpa em frutos de cultivares de macieira}

Corresponding author: ricardosakini@gmail.com

Received: October 28, 2019 Accepted: February 11, 2020

Copyright: All the contents of this journal, except where otherwise noted, is licensed under a Creative Commons Attribution License.
Resumo- A maçã é considerada um alimento funcional, pois apresenta uma considerável contribuição no aporte de antioxidantes, vitaminas e minerais, e seu consumo está relacionado à prevenção de várias doenças. Porém, a maior parte das cultivares lançadas nos últimos anos ainda foi pouco estudada com relação às suas propriedades nutricionais. $\mathrm{O}$ objetivo do trabalho foi quantificar teores minerais na casca $\mathrm{e}$ na polpa, em frutos de cultivares de macieiras com potencial de produção no Sul do Brasil. Foram avaliadas as cultivares Fuji Suprema, Castel Gala, Lisgala, Monalisa, Luíza, Daiane, Venice, Elenise e a seleção avançada M.10-09, nas safras de 2017/2018 e 2018/2019. Entre os minerais avaliados, considerando o consumo de um fruto de $115 \mathrm{~g}$ (exceto carpelo e sementes), o potássio supre a maior porcentagem da ingestão diária recomendada para o organismo, seguido do fósforo e do magnésio. O cálcio presente em maçãs apresenta baixa contribuição para o suprimento da ingestão diária. Devido às maiores concentrações dos minerais na casca em relação à polpa, o consumo dos frutos inteiros aumenta o percentual de minerais ingeridos. Ainda, os minerais avaliados apresentaram diferenças significativas em função da cultivar. A cultivar Monalisa, na porção polpa, destacou-se pelos elevados teores minerais de fósforo e de cálcio, com 204,1 e $36,5 \mathrm{mg} \mathrm{kg}^{-1}$ (2017/2018) e 305,6 e 43,8 $\mathrm{mg} \mathrm{kg}^{-1}$ (2018/2019), respectivamente. A cultivar Fuji Suprema, em ambas as safras avaliadas, destacou-se devido aos elevados teores minerais de potássio, na casca $\left(1.073,8 \mathrm{mg} \mathrm{kg}^{-1}\right)$ e na polpa $\left(1.223,7 \mathrm{mg} \mathrm{kg}^{-1}\right)$, em $2017 / 2018$, e na polpa $\left(1.547,3 \mathrm{mg} \mathrm{kg}^{-1}\right) \mathrm{em}^{-}$ $2018 / 2019$, e magnésio na polpa $\left(122,4 \mathrm{mg} \mathrm{kg}^{-1}\right) \mathrm{em} 2017 / 2018$, e na casca $\left(231,2 \mathrm{mg} \mathrm{kg}^{-1}\right)$ e na polpa $(62,4$ $\mathrm{mg} \mathrm{kg}^{-1}$ ) em 2018/2019.

Termos para indexação: Malus domestica. Status nutricional. Nutrição alimentar.

\footnotetext{
Agronomist, Master in Plant Production. Santa Catarina State University - UDESC - Lages - SC, Brazil. Email: ricardosakini@gmail.com (ORCID 0000-0001-8687-0856)

${ }^{2}$ Agronomist, PhD, Professor at the Santa Catarina State University- UDESC - Lages - SC, Brazil. Email: cristiano.steffens@udesc.br ${ }^{(0 R C I D} 0000-0003-$ 0936-8656)

${ }^{3}$ Agronomist, PhD, Researcher, Agricultural Research and Rural Extension Company of Santa Catarina - EPAGRI, São Joaquim - SC, Brazil. Email: mariucciamartin@epagri.sc.gov.br(ORDID 0000-0002-6857-5594)

${ }^{4}$ Chemist, PhD, Researcher, Agricultural Research and Rural Extension Company of Santa Catarina - EPAGRI, Caçador - SC, Brazil. Email: biancaschveitzer@epagri.sc.gov.br (ORCID 0000-0001-9309-2765)

${ }_{5}^{5}$ Agronomist, M. S., PhD student in Plant Production. Santa Catarina State University - UDESC - Lages - SC, Brazil. Email: cristhianfenili@ hotmail.com (ORCID 0000-0003-4940-4789)

${ }^{6}$ Agronomist, M. S., Researcher, Agricultural Research and Rural Extension Company of Santa Catarina - EPAGRI, Caçador - SC, Brazil. Email: petri@epagri.sc.gov.br(ORCID 0000-0003-1485-7171)
} 


\section{Introduction}

Brazil has rich biodiversity, standing out due to the existence of several fruits, with different color, aroma, shape and nutritional value. The consumption of fruits and vegetables is becoming increasingly popular, providing essential components for human diet such as minerals, fibers, vitamins, carbohydrates and antioxidant protection (FIB, 2009). Apple is the fruit of temperate climate with the greatest dispersion, commercialization and consumption as fresh fruit in the world, being the fourth most produced fruit, only behind citrus, grapes and bananas (HAUAGGE; BRUCKNER, 2002; FURLAN et al., 2010). In 2018, apple production in Brazil exceeded one million tons (ANUÁRIO, 2018).

At the time of purchase, fruit consumers initially evaluate attributes related to appearance, such as size, shape, color and absence of defects. Only after purchase, during consumption, internal quality attributes such as absence of physiological disorders in the flesh, texture and flavor, will be evaluated. This moment is critical in the decision to make a new purchase, especially if these attributes are also associated with health benefits (MUSACCHI; SERRA, 2018).

Among the many benefits of apple consumption to human health, its role as a source of minerals should be highlighted. Considered the most abundant mineral in the human body, calcium is present in about $90 \%$ of the skeleton, and the rest is mainly divided between muscles and blood plasma. The mineral is considered primordial in controlling the permeability of the cell membrane, plays a role in the contractions of muscle fibers, release of hormones and mediators of the nervous system, and in blood coagulation (FIORINI, 2008). Phosphorus plays a structural role in the cell and constituents of cell membranes, in the cell as a source of energy in the form of ATP (adenosine triphosphate) and in numerous enzymatic activities. This mineral is present in the human body, together with calcium, in the skeleton, about 70 to $85 \%$, and in soft tissues, liver, spleen and muscles (FIORINI, 2008; MONTEIRO; VANNUCCHI, 2010). Magnesium is involved in calcium metabolism, in the synthesis of vitamin D and in the formation of the bone skeleton mineral structure. It is required for the metabolism of carbohydrates, proteins and lipids. It is vital for the health of muscle and nervous tissues, regulates the activity of more than 300 enzymatic reactions, in the duplication of nucleic acids, transmission of nervous influx, neural excitability and acts on the ion exchange of the cell membrane (FAO; WHO, 2001). Potassium is the most important intracellular cation and contributes to the metabolism and to the synthesis of proteins and glycogen. It also controls $\mathrm{pH}$ levels, osmotic pressure and water balance in body spaces through the sodiumpotassium pump, and blood pressure. In the blood plasma, the amount of potassium is very small; however, the total absence of this cation is a sign of nutritional deficit (FIORINI, 2008).

Currently, the main apple cultivars produced in Brazil are 'Gala' and 'Fuji' and their colored clones, which represent around $60 \%$ and $30 \%$ of production, respectively (PETRI et al., 2011). New apple cultivars have been developed in recent years in Brazil, which have a number of advantages, in addition to diversification for the consumer market and good adaptation to climatic conditions in the southern region of Brazil. In addition, these new cultivars show resistance to the main diseases that affect apple culture, allowing a significant reduction in the application of pesticides (KVITSCHAL et al., 2018).

Mineral contents in apples vary depending on the cultivar, production cycle and growing region (AMARANTE et al., 2012; BRUNETTO et al., 2015; SCHVEITZER et al., 2019). In this sense, although there is available information about the average levels of minerals in 'Gala' and 'Fuji' cultivars (AMARANTE et al., 2012), little is known about the mineral composition of cultivars recently developed in Brazil. Therefore, the aim of this study was to quantify the mineral contents in the skin and flesh, separately, in fruits of apple cultivars with production potential in Southern Brazil.

\section{Material and methods}

The experiment was conducted using fruits from the experimental orchard of the Agricultural Research and Rural Extension Company of Santa Catarina (Epagri), located at the Caçador Experimental Station, SC, harvested in the 2017/2018 and 2018/2019 seasons. The experiment used fruits of the following cultivars: 'Epagri 405 Fuji Suprema' (Fuji mutation), 'Castel Gala' (Gala mutation) (2017/18), 'Epagri 407 Lisgala' (Gala mutation) (2018/19), 'SCS 417 Monalisa' (Gala우 x Malus 4§), 'SCS 425 Luiza' (Imperatrizo x Cripps Pink ${ }^{\Uparrow}$ ), 'Daiane' (Gala $\circ$ x Princesa ${ }^{\Uparrow}$ ), 'SCS 426

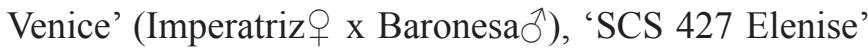
(Imperatriz + x Cripps Pink ${ }^{\top}$ ) and 'M.10-09 advanced selection' (Imperatriz + x Cripps Pink $\circlearrowleft$ ), from the same orchard, implanted in August 2012, with planting density of 2,500 plants ha ${ }^{-1}$, on M-9 rootstock, conducted in the central leader system, with spacing of $1.0 \mathrm{~m}$ between plants and $4.0 \mathrm{~m}$ between rows. The management practices used in the orchard and the definition of the maturation stage for harvesting were carried out as recommended for the Apple Production System (SEZERINO, 2018). After harvesting, diameter standardization was performed, and fruits with rot, lesions or defects were eliminated.

Five replicates of each cultivar consisting of 10 fruits each were randomly selected for the determination 
of the mineral contents of phosphorus $(\mathrm{P})$, potassium $(\mathrm{K})$, calcium $(\mathrm{Ca})$ and magnesium $(\mathrm{Mg})$ in the skin and flesh portions of fruits at the Laboratory Chemical Testing, located at Epagri - Experimental Station of Caçador, SC, totaling 10 samples per cultivar and 40 samples per evaluated season. The skin portion was composed of a thin layer of the epidermis of the entire fruit surface, manually extracted with the aid of cutting blades, avoiding flesh remnants. The flesh portion consisted of a $1-\mathrm{cm}$ thick longitudinal slice, in the shape of a wedge, without skin and without the central part of the fruit (carpel and seeds), manually removed with the aid of cutting blades. With the aid of a 700-watt Philco mixer, the processing (crushing) of portions removed from fruits that composed the samples was carried out separately in a transparent $1000 \mathrm{~mL}$ container. Subsequently, $5.0 \mathrm{~g}$ of fresh weight (FW) of crushed parts were weighted on a SHIMADZU semi-analytical scale model AUY 220, which were packed in glass tubes of $50 \mathrm{~mm}$ in diameter and $250 \mathrm{~mm}$ in height, remaining in heating blocks with electronic temperature controller for solubilization in concentrated sulfuric acid $\left(\mathrm{H}_{2} \mathrm{SO}_{4}\right)$ from Reatec and $30 \%$ hydrogen peroxide $\left(\mathrm{H}_{2} \mathrm{O}_{2}\right)$ from Synth, inside a gas fume hood, according to methodology described by Schveitzer and Suzuki (2013). After the solubilization process, for K, Mg and $\mathrm{Ca}$ analyses, samples remained at room temperature and the digested extract was gradually added, remaining in the tube $50 \mathrm{~mL}$ of distilled water $\left(\mathrm{H}_{2} \mathrm{O}\right)$. From the initial extract, with the aid of an automatic pipette model KASVI - Premium Black, $10 \mathrm{~mL}$ were removed and transferred to neutral glass test tubes, without cover and rounded bottom, with $16 \mathrm{~mm}$ in diameter and $150 \mathrm{~mm}$ in length, and $3.5 \mathrm{~mL}$ of $0.4 \%$ La was added for Ca reading. From the dilution performed for $\mathrm{Ca}, 1 \mathrm{~mL}$ was removed with the aid of automatic pipette and transferred to test tubes (same characteristics as above) and $15 \mathrm{~mL}$ of distilled water were added for $\mathrm{K}$ and $\mathrm{Mg}$ reading. The readings of elements were performed on PerkinElmer ${ }^{\mathbb{B}}$ atomic absorption spectrophotometer model AAnalyst 200 (Waltham, USA) through PerkinElmer ${ }^{\mathbb{R}}$ Lumina $^{\mathrm{TM}}$ Lamp hollow cathode lamps, specific for each element (Waltham, USA). For P analysis, with the aid of automatic pipette model KASVI - Premium Back, $5.0 \mathrm{~mL}$ were removed from the initial extract, transferring to neutral glass test tubes without cover and round bottom and 16 $\mathrm{mm}$ in diameter and $150 \mathrm{~mm}$ in length, adding $5.0 \mathrm{~mL}$ of distilled water and $4.0 \mathrm{~mL}$ of the molybdate/vanadate indicator (1:1), both from VETEC, forming a yellowish color which absorbs light wave at 420 nanometers (nm). After adding the indicator, the solution rested for $30 \mathrm{~min}$ at room temperature, and the absorbance was read on Varian ${ }^{\circledR} \mathrm{UV}$-visible spectrophotometer (Palo Alto, USA) at $420 \mathrm{~nm}$. Through the values obtained in readings, nutrient contents were quantified in $\mathrm{mg} \mathrm{kg}^{-1}$ of fresh weight (FW).
Data were submitted to analysis of variance (ANOVA) and means compared by the Scott Knott test $(\mathrm{p}<0.05)$ using the SISVAR statistical software (FERREIRA, 2008) version 5.6.

\section{Results and discussion}

In the skin portion during the $2017 / 18$ season, $\mathrm{P}$ showed higher concentration in the Monalisa cultivar $\left(242.6 \mathrm{mg} \mathrm{kg}^{-1}\right)$. The lowest levels were observed in 'Luiza' (173.6 mg kg-1) and M.10-09 (155.8 $\mathrm{mg} \mathrm{kg}^{-1}$ ) (Figure 1). In the flesh portion, the highest concentrations were observed for 'Monalisa' (204.1 $\left.\mathrm{mg} \mathrm{kg}^{-1}\right)$, 'Daiane', 'Venice' and 'Fuji Suprema' (214.4 $\left.\mathrm{mg} \mathrm{kg}^{-1}\right)$. The lowest concentration was found in M.10-09 $\left(103.6 \mathrm{mg} \mathrm{kg}^{-1}\right)$. In the skin portion, in fruits of the $2018 / 19$ season, the highest P concentration was found for Venice cultivar $(630.6 \mathrm{mg}$ $\left.\mathrm{kg}^{-1}\right)$. The lowest levels in this portion were observed for 'Elenise' (239.9 mg kg-1), 'Fuji Suprema' (254.4 mg kg$\left.{ }^{1}\right)$ and M.10-09 (252.7 $\left.\mathrm{mg} \mathrm{kg}^{-1}\right)$ (Figure 1). For the flesh portion, in the second season, 'Monalisa' and 'Lisgala' presented the highest $\mathrm{P}$ concentrations, 305.6 and 289.1 $\mathrm{mg} \mathrm{kg}^{-1}$, respectively. The lowest levels of this mineral were found for M.10-09 (22.7 $\left.\mathrm{mg} \mathrm{kg}^{-1}\right)$, 'Elenise' (24.2 $\mathrm{mg} \mathrm{kg}^{-1}$ ) and 'Fuji Suprema' (30.5 $\left.\mathrm{mg} \mathrm{kg}^{-1}\right)$.

When consuming an apple without skin, a significant portion of minerals is wasted. Brasil (2005) recommends daily $\mathrm{P}$ intake of $700 \mathrm{mg}$ for adults and adolescents. An adult can absorb around 55 to $70 \%$ of ingested $\mathrm{P}$. This absorption depends basically on the intestinal $\mathrm{pH}$ conditions, and the more acid in the duodenum portion, the greater the P solubility, increasing $P$ bioavailability to the organism (MONTEIRO; VANNUCCHI, 2010).

Considering the average of cultivars in the two years of $\mathrm{P}$ evaluation of each portion (Table 1), the consumption of a fruit with approximately $100 \mathrm{~g}$ of flesh, without skin and without inedible parts (carpel and seeds), provides average $\mathrm{P}$ amount of $15.5 \mathrm{mg}$, corresponding to $2.2 \%$ of the recommended daily intake (RDI) for adults. When the same fruit is consumed with skin (considering skin weight of approximately $15 \mathrm{~g}$ ), the amount of mineral ingested increases by $0.6 \%$. In this sense, the consumption of a fruit with about $100 \mathrm{~g}$ of flesh and $15 \mathrm{~g}$ of skin corresponds to approximately $2.8 \%$ of the RDI of the mineral for adults. 


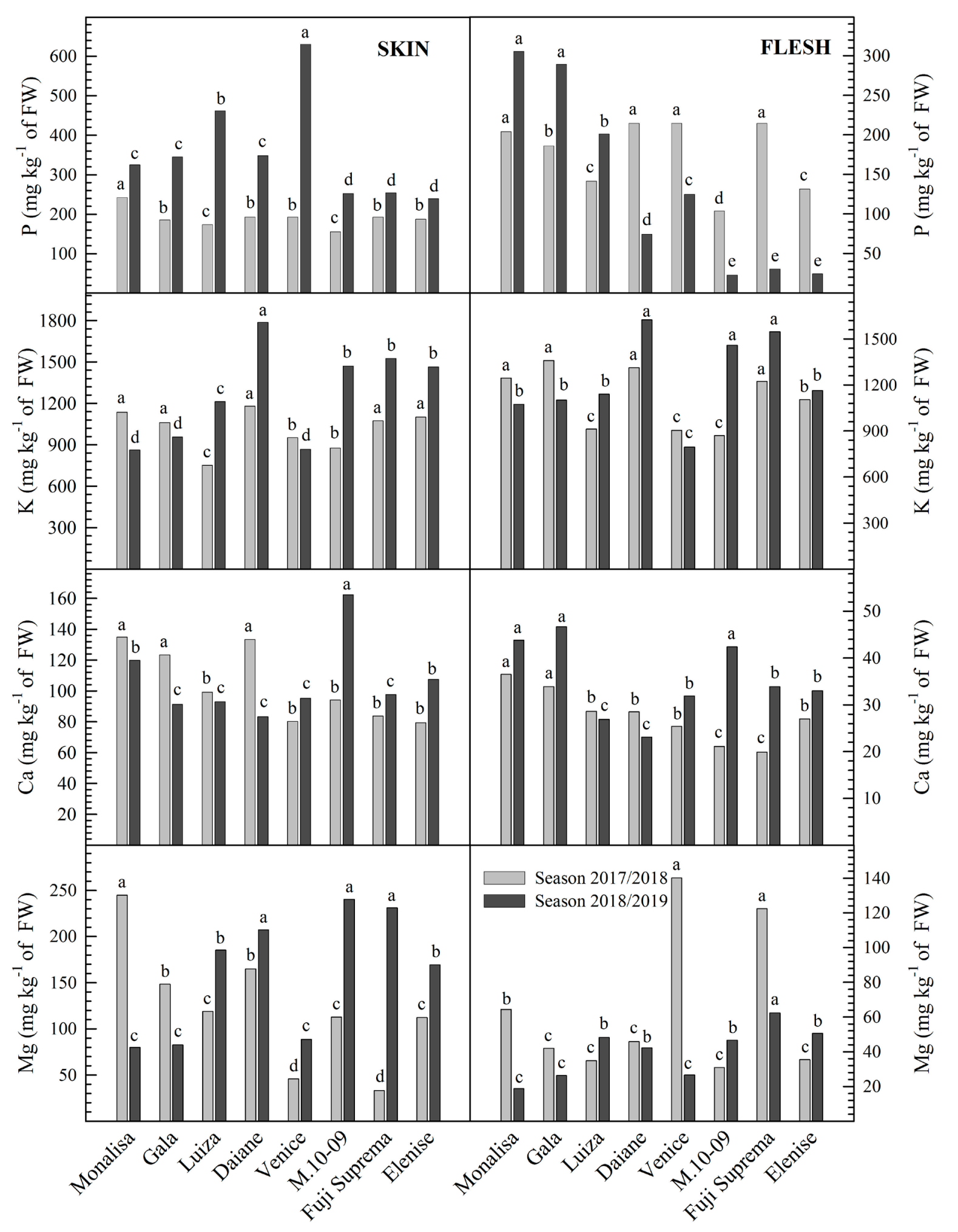

Cultivar

Figure 1. Phosphorus (P), Potassium (K), Calcium (Ca) and Magnesium $(\mathrm{Mg})$ contents $\left[\mathrm{mg} \mathrm{kg}^{-1}\right.$ of fresh weight (FW)] in skin and flesh of apple cultivars evaluated in two consecutive harvest seasons (2017/2018 and 2018/2019). Means followed by distinct letters, between columns of the same color, differ from each other by the Scott-Knott test $(\mathrm{p}<0.05)$. 
Table 1 - General averages of the of Phosphorus (P), Potassium (K), Calcium (Ca) and Magnesium (Mg) contents [mg kg-1 of fresh weight (FW)] in the skin and flesh of apple cultivars in the 2017/2018 and 2018/2019 harvest seasons. Caçador, SC, 2019.

\begin{tabular}{|c|c|c|c|c|}
\hline \multirow{3}{*}{ Year/Season } & $\mathbf{P}$ & $\mathbf{K}$ & $\mathbf{C a}$ & Mg \\
\hline & \multicolumn{4}{|c|}{--- $\mathrm{mg} \mathrm{kg}^{-1}$ of FW ---- } \\
\hline & \multicolumn{4}{|c|}{ SKIN } \\
\hline $2017 / 2018$ & 190,6 & 1016,3 & 103,6 & 122,7 \\
\hline 2018/2019 & 357,3 & 1463,8 & 106,3 & 160,6 \\
\hline Average two harvest seasons & 273,9 & 1240,0 & 104,9 & 141,6 \\
\hline \multirow{2}{*}{ Samples/harvest } & & & & \\
\hline & \multicolumn{4}{|c|}{ FLESH } \\
\hline $2017 / 2018$ & 176,2 & 1116,6 & 27,6 & 64,5 \\
\hline $2018 / 2019$ & 134,0 & 1238,2 & 35,2 & 40,3 \\
\hline Average two harvest seasons & 155,1 & 1177,4 & 31,4 & 52,4 \\
\hline Samples/harvest & \multicolumn{4}{|c|}{40} \\
\hline
\end{tabular}

In the skin portion in the 2017/18 harvest season, the highest $\mathrm{K}$ concentration was observed for 'Monalisa' (1135.9 mg kg-1), 'Castel Gala' (1061.0 mg $\mathrm{kg}^{-1}$ ), 'Daiane' (1179.5 $\left.\mathrm{mg} \mathrm{kg}^{-1}\right)$, 'Fuji Suprema' (1073.8 $\left.\mathrm{mg} \mathrm{kg}{ }^{-1}\right)$ and 'Elenise' $\left(1100.3 \mathrm{mg} \mathrm{kg}^{-1}\right)$ and the lowest $\mathrm{K}$ concentration for 'Luiza' (751.4 $\mathrm{mg} \mathrm{kg}^{-1}$ ) (Figure 1). 'Venice' and M.10-09 presented intermediate values for this mineral, with no differences from each other. In the flesh portion, the highest $\mathrm{K}$ concentrations were observed in 'Monalisa' (1245.1 $\mathrm{mg} \mathrm{kg}^{-1}$ ), 'Castel Gala' (1359.7 $\left.\mathrm{mg} \mathrm{kg}{ }^{-1}\right)$, 'Daiane' (1313.1 $\mathrm{mg} \mathrm{kg}^{-1}$ ) and 'Fuji Suprema' (1223.7 mg kg-1). 'Elenise' showed intermediate value of this mineral, while 'Luiza' (912.2 mg kg-1), 'Venice' (903.9 $\mathrm{mg} \mathrm{kg}^{-1}$ ) and M.10-09 (870.0 $\mathrm{mg} \mathrm{kg}^{-1}$ ) presented the lowest concentrations of this mineral in the flesh portion. In the 2018/19 harvest season, the K concentration in the skin portion was higher for Daiane cultivar (1786.8 $\mathrm{mg} \mathrm{kg}^{-1}$ ) (Figure 1). Cultivars with the lowest $\mathrm{K}$ concentrations were 'Monalisa' $(862.9 \mathrm{mg} \mathrm{kg}$ 1), 'Lisgala' (956.6 $\mathrm{mg} \mathrm{kg}^{-1}$ ) and 'Venice' (867.7 mg kg$\left.{ }^{1}\right)$. In the flesh portion, M.10-09 (1459.5 mg kg-1), 'Fuji Suprema' (1547.3 mg kg-1) and 'Daiane' (1624.0 mg $\mathrm{kg}^{-1}$ ) presented the highest $\mathrm{K}$ concentrations. The lowest $\mathrm{K}$ concentration was observed in the flesh of Venice cultivar $\left(794.7 \mathrm{mg} \mathrm{kg}^{-1}\right)$.

Virtually all K consumed through food is absorbed in the gastrointestinal tract and directly transported to the liver. This organ is responsible for regulating $\mathrm{K}$ balance and excretion. In the United States, the average $\mathrm{K}$ intake for men is 2.8 to $3.3 \mathrm{~g} \mathrm{day}^{-1}$ and for women 2.2 to $2.4 \mathrm{~g}$ day $^{-1}$. There are no data on the daily potassium intake for the Brazilian population (CUPPARI; BAZANELLI, 2010). According to the World Health Organization (WHO), adults need to consume around 3,510 mg of K per day. Low $\mathrm{K}$ intake can cause health problems, such as increased blood pressure, increased risk of stroke and development of heart disease (WHO, 2016).

When considering the average among cultivars of the two years of $\mathrm{K}$ evaluation of each analyzed portion
(Table 1), the consumption of a fruit with approximately $100 \mathrm{~g}$ of flesh, without skin and without inedible parts (carpel and seeds), provides $\mathrm{K}$ amount of approximately $117.7 \mathrm{mg}$. When the same fruit is consumed with the skin (considering the skin weight of approximately $15 \mathrm{~g}$ ), it provides an additional $18.6 \mathrm{mg}$ of the mineral. Therefore, the consumption of a fruit with about $100 \mathrm{~g}$ of flesh and $15 \mathrm{~g}$ of skin would correspond to $3.8 \%$ of RDI for adults.

In the skin portion, the highest $\mathrm{Ca}$ concentration in the $2017 / 18$ harvest season was observed for 'Monalisa' (134.9 $\left.\mathrm{mg} \mathrm{kg}^{-1}\right)$, 'Castel Gala' (123.4 mg kg-1) and 'Daiane' $\left(133.4 \mathrm{mg} \mathrm{kg}^{-1}\right)$. The other cultivars did not differ from each other (Figure 1). In the flesh portion, the highest $\mathrm{Ca}$ concentrations were observed for 'Monalisa' (36.5 mg kg-1) and 'Castel Gala' (33.9 $\left.\mathrm{mg} \mathrm{kg}^{-1}\right)$. 'Fuji Suprema' (19.9 mg kg-1) and M.10-09 (21.1 $\left.\mathrm{mg} \mathrm{kg}^{-1}\right)$ showed the lowest $\mathrm{Ca}$ concentrations in the first harvest season. In the skin portion in the 2018/19 harvest season, Ca concentration was higher for M.10-09 (162.4 $\left.\mathrm{mg} \mathrm{kg}^{-1}\right)$ (Figure 1). The lowest $\mathrm{Ca}$ concentrations were observed for 'Lisgala' (91.3 mg kg-1), 'Luiza' (93.1 mg kg-1), 'Daiane' (83.3 $\left.\mathrm{mg} \mathrm{kg}^{-1}\right)$, 'Venice' (95.3 $\mathrm{mg} \mathrm{kg}^{-1}$ ) and 'Fuji Suprema' (97.6 $\left.\mathrm{mg} \mathrm{kg}^{-1}\right)$. In the flesh portion, M.10-09 (42.4 mg kg${ }^{-1}$ ), 'Lisgala' (46.7 $\mathrm{mg} \mathrm{kg}^{-1}$ ) and 'Monalisa' (43.8 $\mathrm{mg} \mathrm{kg}^{-1}$ ) presented the highest Ca concentrations. The lowest $\mathrm{Ca}$ concentrations were observed for Daiane (23.1 $\left.\mathrm{mg} \mathrm{kg}^{-1}\right)$ and Luiza cultivars $\left(26.9 \mathrm{mg} \mathrm{kg}^{-1}\right)$.

The daily $\mathrm{Ca}$ requirement for children and adolescents is from 700 to $1,300 \mathrm{mg}^{\text {day }}{ }^{-1}$ due to the period in which the body grows rapidly, resulting in the development and deposit of the mineral in bones. In adulthood, the daily $\mathrm{Ca}$ requirement is around $1,000 \mathrm{mg}$ day $^{-1}$, increasing again in older adults from 1,200 to 1,300 $\mathrm{mg} \mathrm{day}^{-1}$ due to the decrease in intestinal absorption and increase in the bone resorption rate (BRASIL, 2005; PEREIRA et al., 2009).

The consumption of a fruit with approximately $100 \mathrm{~g}$ of flesh without skin and without inedible parts (carpel and seeds), considering the average among 
cultivars and the two years of $\mathrm{Ca}$ evaluation of each analyzed portion (Table 1), an amount of approximately $3.1 \mathrm{mg}$ of $\mathrm{Ca}$ would be provided. When the same fruit is consumed with the skin (considering the skin weight of approximately $15 \mathrm{~g}$ ), it provides an additional $1.6 \mathrm{mg}$ of the mineral. Therefore, the consumption of a fruit of approximately $100 \mathrm{~g}$ of flesh and $15 \mathrm{~g}$ of skin would correspond to around $0.46 \%$ of RDI for adults.

In the skin portion in the 2017/18 harvest season, $\mathrm{Mg}$ showed the highest concentration in Monalisa cultivar (244.9 $\mathrm{mg} \mathrm{kg}^{-1}$ ). The lowest $\mathrm{Mg}$ levels were observed for 'Venice' (45.9 $\left.\mathrm{mg} \mathrm{kg}^{-1}\right)$ and 'Fuji Suprema' (33.3 $\mathrm{mg} \mathrm{kg}^{-1}$ ) (Figure 1). In the flesh portion, the highest $\mathrm{Mg}$ concentrations were observed for 'Venice' (140.1 $\left.\mathrm{mg} \mathrm{kg}^{-1}\right)$, 'Fuji Suprema' (122.4 $\mathrm{mg} \mathrm{kg}^{-1}$ ) and 'Monalisa' (64.4 $\left.\mathrm{mg} \mathrm{kg}^{-1}\right)$. The other cultivars showed lower $\mathrm{Mg}$ concentrations, which did not differ from one another. In the skin portion in the 2018/19 harvest season, the highest $\mathrm{Mg}$ concentrations were observed for M.10-09 (240.4 mg kg-1), 'Fuji Suprema' (231.2 $\mathrm{mg} \mathrm{kg}^{-1}$ ) and 'Daiane' (207.2 $\mathrm{mg} \mathrm{kg}^{-1}$ ) (Figure 1). The lowest $\mathrm{Mg}$ concentrations were found for 'Monalisa' (79.9 mg kg1), 'Lisgala' (82.7 $\left.\mathrm{mg} \mathrm{kg}^{-1}\right)$ and 'Venice' apples $(88.7 \mathrm{mg}$ $\left.\mathrm{kg}^{-1}\right)$. In the flesh portion, Fuji Suprema cultivar showed the highest $\mathrm{Mg}$ concentration $\left(62.4 \mathrm{mg} \mathrm{kg}^{-1}\right)$. 'Monalisa' (18.7 $\left.\mathrm{mg} \mathrm{kg}^{-1}\right)$, 'Lisgala' (26.4 $\left.\mathrm{mg} \mathrm{kg}^{-1}\right)$ and 'Venice' (88.7 $\mathrm{mg} \mathrm{kg}^{-1}$ ), showed the lowest $\mathrm{Mg}$ concentrations.

$\mathrm{Mg}$ intake for adults recommended by Brasil (2005) is $260 \mathrm{mg}$. For children aged 1-10 years, satisfactory daily consumption ranges from 60 to 100 $\mathrm{mg}$. Considering the average among cultivars and the two years of $\mathrm{Mg}$ evaluation of each portion analyzed (Table 1), the consumption of a fruit with approximately $100 \mathrm{~g}$ of flesh, without skin and without inedible parts (carpel and seeds), would provide $5.2 \mathrm{mg}$ of the mineral. If the same fruit is consumed with skin (considering the skin weight of approximately $15 \mathrm{~g}$ ), it would provide additional $2.1 \mathrm{mg}$. Thus, the consumption of a fruit with around $100 \mathrm{~g}$ of flesh and $15 \mathrm{~g}$ of skin would correspond to approximately $2.8 \%$ of RDI for adults and from 7.3 to $12.2 \%$ of RDI for children.

A healthy diet, rich in nutrients and able to supply the daily nutritional needs of the organism, can be complemented with the use of the food parts that are usually discarded. As can be seen in apple cultivars of this study, the highest concentrations of minerals are present in the skin portion, and when it is discarded, significant amount of minerals is lost. In a study comparing different fruits regarding to mineral composition, Gondim et al. (2005) concluded that the skin of fruits has higher nutrient contents compared to other edible parts and can be considered alternative sources of nutrients. In addition to minerals, the skin of fruits has significant amounts of fiber, vitamins and compounds with antioxidant properties (BOYER and LIU, 2004; FIORINI, 2008).
The consumption of apples is a major source of phenolic compounds, and the skin portion provides the highest concentrations (WOLFE et al., 2003; STANGER et al., 2017; 2018).

The different harvest seasons can cause variations in the mineral composition of fruits (AMARANTE et al., 2012). Evaluations clearly showed that some patterns remained in both seasons, demonstrating that some cultivars tend to have higher concentration of certain minerals when compared to others (Figure 1).

'Castel Gala' and 'Lisgala' showed high Ca levels. Among evaluated minerals, Ca present in apples is what provides the lowest nutrient percentage to the organism. In both harvest seasons, Daiane cultivar presented the high $\mathrm{K}$ concentrations, both in flesh and skin portions.

Monalisa cultivar presented the highest $\mathrm{P}$ and $\mathrm{Ca}$ concentrations in both harvest seasons. This cultivar stands out for presenting good appearance and high taste quality. In addition, it is resistant to the main diseases that affect apple culture (glomerella leaf spot and apple scab), and is well adapted to the climatic conditions of southern Brazil, allowing reduction in the use of agrochemicals compared to traditional Gala and Fuji cultivars (DENARDI et al., 2013).

In both harvest seasons, 'Fuji Suprema' presented high K concentrations in both flesh and skin, which mineral is one with the greatest contribution to the organism with the consumption of apples. In the same cultivar, the $\mathrm{Mg}$ content stood out in both harvest seasons. $\mathrm{Mg}$ intake is important especially for children, as it has significant in recommended daily intake (RDI) percentage in this age group. One of the main characteristics of Fuji Suprema cultivar is in relation to its color, which covers about $80 \%$ of the fruit, presenting a solid red color, attracting consumers attention at the time of purchase (CAMILO; DENARDI, 2006).

Although some cultivars present greater RDI contribution of certain minerals compared to others, all materials evaluated represent a significant supply to the organism, especially for the Brazilian population, where apple is considered the third most consumed fruit (IBGE, 2010).

The mineral composition of fruits is related not only to their nutritional quality and benefits to human health, but also to postharvest behavior, which may influence their susceptibility to physiological disorders and storage capacity (AMARANTE et al., 2012; SCHVEITZER et al., 2019). In a study with different apple cultivars using a wedge (flesh + skin) to assess the mineral composition of fruits, Schveitzer et al. (2019) found variations in mineral content not only among cultivars, but also among years. According to the authors, these results may justify the variation in susceptibility to physiological disorders observed in cultivars and seasons. In this sense, the results obtained in the present study can also help 
to understand the physiology and behavior of new apple cultivars grown in Brazil in recent years.

\section{Conclusions}

Variations among mineral contents were observed in cultivars recommended for cultivation in southern Brazil.

According to ANVISA's daily mineral intake recommendations, the $\mathrm{K}$ present in apples supplies the highest percentage to organism, followed by $\mathrm{P}$ and $\mathrm{Mg}$. Ca present in apples has low contribution to the supply of the RDI.

'Monalisa' stood out due to the high P levels in skin and flesh in the 2017/18 harvest season (242.6 and $204.16 \mathrm{mg} \mathrm{kg}^{-1}$ ) and flesh, in the 2018/19 harvest season (305.6 m k k ${ }^{-1}$ ) and $\mathrm{Ca}$ in skin and flesh in the 2017/18 harvest season (134.9 and $36.5 \mathrm{mg} \mathrm{kg}^{-1}$ ) and flesh, in the 2018/19 harvest season $\left(43.8 \mathrm{mg} \mathrm{kg}^{-1}\right)$.

'Fuji Suprema' stood out due to the high K levels in skin and flesh in the 2017/18 harvest season (1073.8 and $1223.7 \mathrm{mg} \mathrm{kg}^{-1}$ ) and flesh in the 2018/19 harvest season $\left(1547.3 \mathrm{mg} \mathrm{kg}^{-1}\right)$ and $\mathrm{Mg}$ in flesh in the 2017/18 harvest season (122.4 $\left.\mathrm{mg} \mathrm{kg}^{-1}\right)$ and in skin and flesh in the 2018/19 harvest season (231.2 and $62.4 \mathrm{mg} \mathrm{kg}^{-1}$ ).

\section{References}

AMARANTE, C.V.T. do; ARGENTA, L.C.; BASSO, C.; SUZUKI, A. Composição mineral de maçãs 'Gala' e 'Fuji' produzidas no Sul do Brasil. Pesquisa Agropecuária Brasileira, Brasília, DF, v.47, p.550-560, 2012.

ANUÁRIO. Anuário brasileiro da maçã 2018. Santa Cruz do Sul: Editora Gazeta, 2018. 56 p.

BOYER, J.; LIU, R. H. Apple phytochemicals and their health benefits. Nutrition Journal, Londres, v. 3, p. $1-15,2004$

BRASIL. Resolução RDC no 269, de 22 de setembro de 2005. Regulamento Técnico sobre a Ingestão Diária Recomendada (IDR) de Proteína, Vitaminas e Minerais. Diário Oficial da União, Brasília, DF, p.6, 23 set. 2005.

BRUNETTO, G.; MELO, G. W. B de; TOSELLI, M.; QUARTIERI, M.; TAGLIAVIN, M. The role of mineral nutrition on yields and fruit quality in grapevine, pear and apple. Revista Brasileira de Fruticultura, Jaboticabal, v.37, p.1089-1104, 2015.
CAMILO, A. P.; DENARDI, F. Cultivares: descrição e comportamento no sul do Brasil. In: EPAGRI. A cultura da macieira. 2. ed. Florianópolis, 2006. p.113-168.

CUPPARI, L.; BAZANELLI, A. P. Funções Plenamente Reconhecidas de Nutrientes: Potássio. International Life Sciences Institute do Brasil, São Paulo, v.11, p.16, 2010.

DENARDI, F.; CAMILO, A.P.; KVITSCHAL, M.V. SCS 417 Monalisa: cultivar de macieira com boa adaptação climática no Sul do Brasil e resistência múltipla a doenças e pragas. Revista Agropecuária Catarinense, Florianópolis, v.26, p.56-62, 2013.

FERREIRA, D. F. SISVAR: Um programa para análises e ensino de estatística. Revista Científica Symposium, Lavras, v.6, p.36-41, 2008.

FAO; WHO. Human vitamin and mineral requirements. Roma: Food and Nutrition Division, 2001.

FIB. Dossiê antioxidantes. São Paulo: Food Ingredients Brasil, 2009. p.16-30.

FIORINI, L. S. Dossiê: os minerais na alimentação São Paulo: Food Ingredients Brasil, 2008. p.48-59.

FURLAN, C.R.C.; DANTAS, A.C.M.; DENARDI, F.; BECKER, W.F.; MANTOVANI, A. Resistência genética dos acessos do banco de germoplasma de macieira da Epagri à mancha foliar de glomerella (Colletotrichum gloeosporioides). Revista Brasileira de Fruticultura, Jaboticabal, v.32, p.507-514, 2010.

GONDIM, J.A.M.; MOURA, M.de F.V.; DANTAS, A.S.; MEDEIROS, R.L.S.; SANTOS, K.M. Composição centesimal e de minerais em cascas de frutas.Ciência e Tecnologia de Alimentos, Campinas, v.25, p.825-827, 2005.

HAUAGGE, R.; BRUCKNER, C. H. Macieira. In: BRUCKNER, C. H. Melhoramento de fruteiras de clima temperado. Viçosa: UFV, 2002. p.28-88.

IBGE- Instituto Brasileiro de Geografia e Estatística. Aquisição alimentar domiciliar per Capita: Brasil e grandes regiões. Rio de Janeiro, 2010. 282 p.

KVITSCHAL, M.V.; HAWERROTH, M.C.; BRIGHENTI, A.F. Novas variedades de maçã no Brasil: situação atual, tendências e perspectivas. In: SEMINÁRIO NACIONAL SOBRE FRUTICULTURA DE CLIMA TEMPERADO, 13., 2018, São Joaquim. Anais [...]. Florianópolis: EPAGRI, 2018, p.126-132. 
MONTEIRO, T.H.; VANNUCCHI, H. Funções plenamente reconhecidas de nutrientes: fósforo. ILSI Brasil, São Paulo, v.15, p.20, 2010.

MUSACCHI, S.; SERRA, S. Apple fruit quality: Overview on pre-harvest factors. Scientia Horticulturae, Amsterdam, v.234, p.409-430, 2018.

PEREIRA, G.A.P.; GENARO, P.S.; PINHEIRO, M.M.; SZEJNFELD, V.L.; MARTINI, L.A. Cálcio dietético: estratégias para otimizar o consumo. Revista Brasileira Reumatologia, São Paulo, v.49, p.164-180, 2009.

PETRI, J. L.; LEITE, G. B.; COUTO, M.; FRANCESCATTO, P. Avanços na cultura da macieira no Brasil. Revista Brasileira de Fruticultura, Jaboticabal, v.33, n.1, p.48-56, 2011.

SCHVEITZER, B.; SACHINI, R.; FENILI, C. L.; DE MARTIN, M. S.; PETRI, J. L. Teores minerais em diferentes cultivares de maçãs nas safras de 2016/17 e 2017/18. In: ZUFFO, A.M. (org.). A produção do conhecimento nas ciências agrárias e ambientais. Ponta Grossa: Atena Editora, 2019. v.5, p.114-124.

SCHVEITZER, B.; SUZUKI, A. Métodos de análises químicas de polpa fresca de maçã. Florianópolis: Epagri, 2013. 23 p. (Documento, 241)
SEZERINO, A. A. (Org.). Sistema de produção para a cultura da macieira em Santa Catarina. Epagri, 2018. 136 p. (Sistemas de produção, 136).

STANGER, M.C.; STEFFENS, C.A.; SOETHE, C.; MOREIRA, M.A.; AMARANTE, C.V.T.do; BOTH, V.; BRACKMANN, A. Phenolic compounds content and antioxidant activity of 'Galaxy' apples stored in dynamic controlled atmosphere and ultralow oxygen conditions. Postharvest Biology and Technology, Amsterdam, v.144, p.70-76, 2018.

STANGER, M.C.; STEFFENS, C.A.; SOETHE, C.; MOREIRA, M.A.; AMARANTE, C.V.T. do. Phenolic content and antioxidant activity during the development of 'Brookfield' and 'Mishima' Apples. Journal of Agricultural and Food Chemistry, Washington, v.65, p.3453-3459, 2017.

WHO- World Health Organization. A healthy lifestyle. 2016. Disponível em http://www.euro.who.int/en/healthtopics/disease-prevention/nutrition/a-healthy-lifestyle. Acesso em: 10 out. 2019.

WOLFE, K.; WU, X.; LIU, R.H. Antioxidant activity of apple peels. Journal of Agricultural and Food Chemistry, Washington, v.51, p.609-614, 2003. 